\title{
O DIREITO ATRAVÉS DA LITERATURA DE BERNARDO ÉLIS: UMA ANÁLISE BOURDIENIANA DO CONTO “A ENXADA”, SOB PERSPECTIVA AGRÁRIO- CONSTITUCIONAL
}

\author{
Hillary Suellen da Silva Freitas ${ }^{1}$ \\ Yasmin Kimura Taketomi Olímpio ${ }^{2}$ \\ Lucas Gomes de Lima ${ }^{3}$
}

RESUMO: A obra literária de Bernardo Élis é responsável por dar maior destaque à realidade do trabalhador rural. Em seus trabalhos, notadamente marcados por denúncias das condições desumanas às quais o camponês está submetido historicamente no Brasil, evidencia a expressiva lacuna de aplicação fática do Direito nesses cenários, instrumento que deveria protegê-lo, promover a justiça social no campo e o dar as mínimas condições para viver dignamente. Nesse sentido, o presente artigo intenta analisar a produção bernardiana intitulada A enxada sob a perspectiva do Direito Agrário Constitucional, compreendendo as condições de produção de (sobre)vivência do personagem Supriano à luz de noções operatórias bourdienianas de Poder Simbólico. Para isso, vale-se da técnica qualitativa de análise de conteúdo, por meio da qual realizamos uma revisão bibliográfica interdisciplinar unindo o jurídico, o literato e o social.

Palavras-chave: Trabalhador rural. Campo. Direito Agrário Constitucional. Literatura. Poder Simbólico.

ABSTRACT: The literary work of Bernardo Élis is responsible for highlighting the reality of rural workers. In his work, marked by denunciations of inhuman conditions to which the peasant is historically subjected in Brazil, it highlights the significant gap in the factual application of the Law in these scenarios, an instrument that should protect it, promote social justice in the countryside and provide the minimum conditions to live with dignity. In this context, the aim of this article is to analyze Bernardo Élis's production titled "A Enxada" from the perspective of Agrarian-Constitutional Law, understanding the conditions of survival of the character Supriano comparing with Bouerdieu's notions of Symbolic Power. For this, it makes use of the qualitative technique of content analysis,

\footnotetext{
I Graduanda em Direito pela Universidade Federal da Paraíba - UFPB e integrante bolsista do LouCid Grupo de Pesquisa e Extensão Loucura e Cidadania da Universidade Federal da Paraíba (UFPB). E-mail: hillarysuellendefreitas@gmail.com.

${ }^{2}$ Graduanda em Direito pela Universidade Federal da Paraíba - UFPB. Integrante do Projeto de Extensão de Preservação da Memória do Curso de Direito da Universidade da Paraíba (UFPB). Monitora bolsista da disciplina de Metodologia do Trabalho Científico. E-mail: yasminkimuratak@gmail.com;

3 Graduando em Direito pela Universidade Federal da Paraíba - UFPB e Monitor da disciplina de Metodologia do Trabalho Científico. E-mail: lucasgomeslimazoı@hotmail.com
} 
through which we carry out an interdisciplinary bibliographic review joining the legal, the literature and the social.

Keywords: Rural worker. Countryside. Agrarian-Constitutional Law. Literature. Symbolic Power.

\section{INTRODUÇÃO}

O presente artigo é resultado do conhecimento e aprendizado adquiridos na práxis acadêmica vivenciada no curso de Bacharelado em Direito do Campus I da Universidade Federal da Paraíba, que incentivou uma aproximação inicial com os variados aspectos conceituais da Pesquisa Aplicada em Direito, da Sociologia Geral e Jurídica, bem como do Direito Agrário sob as lentes do Direito Constitucional.

Considerando que a literatura é um singular instrumento da representação social, bem como de reflexão crítica sobre valores transcendentais que se manifestam na órbita ou no centro do campo jurídico, o presente trabalho busca compreender o narrar de Bernardo Élis no conto A Enxada, a fim de fomentar um novo olhar sobre o Direito e a questão agrária, revelando novas nuances e horizontes até então pouco abordados na intersecção do Direito com a Literatura. A relação imediata entre a ficção e o real, do qual decorre neste as querelas dispostas naquela, enseja uma (re)leitura do texto sob perspectiva jurídico-social, que se justifica pela correspondência entre ambos.

Tendo em conta a superposição do literato no processo social que coloca o texto à imediata realidade da concentração de terras por meio dos latifúndios e suas consequências no definhamento físico e mental do homem do campo, problematiza-se: como se apresenta o Direito ao camponês na realidade social narrada, considerando a ausência dos princípios do Direito Agrário Constitucional na estória A Enxada?

Frente a essa problemática, o estudo visa analisar, sob a perspectiva jurídica, as condições de produção de (sobre)vivência do personagem Supriano frente ao patrão e a reprodução do coronelismo. Para tanto, buscou-se: interpretar os personagens do conto sob a perspectiva da teoria discursiva bourdienianas de Poder Simbólico compreender o Direito Agrário Constitucional à luz do acesso de todos à terra, bem como reconhecer a confluência da literatura bernardiana entre o Direito e a questão agrária. 
A hipótese geral do presente projeto compreende que a sujeição às amarras dos grandes proprietários rurais imbricados no poder econômico e político no interior do país é fruto não da ausência da previsão legal, mas da (des)aplicação fática do Direito. Em relação ao Direito Agrário Constitucional, não se trata apenas de positivá-lo, mas de protegê-lo. isto porque a simples materialização de normas por si, sem sua devida efetivação e limitação dos arbítrios de poderio, perpetuam a servidão dos trabalhadores rurais, uma vez que o poder da classe dos proprietários rurais na sua relação com o Estado parece impedir a disciplina jurídica.

Nesse sentido, por se compreenderem presos ao poder político e econômico dos grandes coronéis sem entraves jurídicos efetivos para controlá-lo, muitos trabalhadores, como Supriano, alienam-se ao sistema que os subjuga, não incitando neste o desejo da mudança, mas a concordância com o mesmo como meio de proteção a si, buscando-se manter ao menos vivo dentro dele.

Cabe dizer, ainda, que a confecção do pretenso trabalho acadêmico vale-se da técnica qualitativa de análise de conteúdo, por meio da qual realizamos uma revisão bibliográfica interdisciplinar acerca do Direito Agrário Constitucional, em conformidade com as obras bernardiana e bourdieniana. No que compreende o método de interpretação, nos valemos do método hermenêutico, investigando o sentido intrínseco à produção literária. Por fim, justifica-se a produção deste trabalho sobre o fato de que o entroncamento do literato com o jurídico, além de servir perfeitamente para desenvolver a sistemática problema-hipótese da pesquisa científica, é capaz de promover sobre o jurista, em sua plenitude, um novo apreciar da construção e aplicação da normativa referente às questões agrárias no país, algo que, até esse dado momento, foi um resultado pouco explorado acerca do recorte pretendido.

\section{O CONTEXTO DA OBRA A ENXADA À LUZ DA TEORIA DISCURSIVA DE PIERRE BOURDIEU}

Situado no espaço agrário goiano, o conto A enxada (1966) de Bernardo Élis narra a história de um trabalhador rural, Supriano, à procura de seu instrumento de trabalho, a enxada. Ao longo da escrita é possível perceber que o personagem batalha arduamente a 
fim de conquistar tal ferramenta, pois é através dela que ele seguirá em prol de sua sobrevivência, arcando suas dívidas e conseguindo seu sustento por meio do labor. Contudo, o utensílio permanece inacessível a ele até a última palavra da obra.

Supriano ou Piano, como também é chamado no decorrer da estória, possuía um débito com o delegado da cidade, que decidiu transferir o poder de cobrança a Elpídio Chaveiro, um famoso latifundiário da região. Este, detentor de poder sobre o camponês, ameaça-lhe tirar sua vida ao cobrar a dívida, caso não se cumprisse o acordado entre ambos - o plantio de sacas de arroz até o dia de Santa Luzia: “(...) tu ainda nesse dia não tiver plantado o arroz te ponho soldado no lombo, rã-rã” (ÉLIS, 1966, p. 87). É aqui que a busca de Supriano por seu instrumento de trabalho inicia.

A luta do protagonista é extremamente difícil, solitária e marcada pelo código do favor e da submissão. Ao longo da trama Supriano recorre aos mais diversos jeitos para conseguir o apetrecho para o plantio. No primeiro momento, ele tenta colher e vender mel para conseguir meios de comprar a enxada. Adiante, submete-se aos suplícios na porteira das terras de seu Elpídio esperando ajuda dos viajantes que por lá passavam e posteriormente ainda pede emprestado o objeto ao Vigário e ao seu colega Joaquim Faleiro, mas sem sucesso em suas tentativas, passa a vagar pelas ruas.

Em caminhada na Rua Palha, Supriano se depara com um conhecido que diz possuir um irmão que poderia ceder-lhe a enxada. No trajeto para Rio Vermelho, local onde esse tal irmão morava, Piano foi surpreendido por dois soldados que o espancaram e o levaram preso sem nenhum motivo aparente, resultando-lhe dois dias na cadeia sem poder fazer nenhuma refeição. Cansado e faminto, foi liberto no que seria o terceiro dia de encarceramento e conduzido à presença de seu Elpídio tornou a ouvir duras palavras e novas ameaças do fazendeiro: “Agora, negro fujão, é pegar o caminho da roça e plantar o arroz, Santa Luzia tá aí” (ÉLIS, 1966, p. 94).

Depois de tanto persistir diante das desfavoráveis situações e, compreendendo que o dia de Santa Luzia chegara, Supriano ficou transtornado, caiu em um delírio e imaginou ter conseguido a enxada, sentindo-a em suas palmas o que inexistia. No ímpeto de salvar sua vida e sua família, sob alucinações, ele planta os grãos de arroz, em pleno amanhecer, 
com as próprias mãos, chegando a dilacerá-las por todo esforço empreendido, mas sem lograr o compromisso feito.

Conforme o acordado entre o camponês e o fazendeiro, os soldados de seu Elpídio se aproximaram para checar se o pacto havia sido cumprido e, conforme as palavras já proferidas por este, seus soldados manobraram o cano do fuzil em direção ao rosto de Supriano, sem piedade alguma. Após a morte do protagonista, dado o dia santo, o conto se enche de um clima festivo, como se nenhuma perda tivesse ocorrido. Sua mulher e filho acabaram por ficar sozinhos, ainda mais vulneráveis e desamparados na luta pela sobrevivência.

A narrativa invoca denúncias em relação às condições desumanas às quais o trabalhador do campo está inserido historicamente no Brasil. Por meio dos personagens principais, Supriano e Elpídio, Bernardo Élis delineia características e comportamentos específicos que traduzem a realidade social nas páginas, o que permite fazer um comparativo entre a realidade retratada no conto e a teoria discursiva bourdieniana de Poder Simbólico.

Para Bourdieu (1989, p. 9), “o poder simbólico é um poder de construção da realidade que tende a estabelecer uma ordem gnoseológica: o sentido imediato do mundo". Sob essa concepção, o sociólogo assinala que o poder se edifica e se revela através dos chamados sistemas simbólicos, sendo estes:

[...] instrumentos estruturados e estruturantes de comunicação e de conhecimento que cumprem a sua função política de instrumentos de imposição ou de legitimação da dominação, que contribuem para assegurar a dominação de uma classe sobre outra (violência simbólica) dando o reforço da sua própria força às relações de força que as fundamentam contribuindo assim para a submissão inconsciente dos dominados (BOURDIEU, 1989, p.ir).

Compreende-se, portanto, que tal poder detém os meios de afirmar o sentido imediato do mundo, instituindo valores, hierarquias e conceitos que se apresentam aos indivíduos como espontâneos através dos sistemas simbólicos, funcionando como instrumentos de dominação e transmutando-se, na sociedade de consumo, em forma de bens e signos de diferentes distinções, como roupas, pronúncia, e quaisquer propriedades do sujeito que podem ser apropriadas e utilizadas em uma tradução simbólica do corpo social. 
No conto, é possível identificar pelo menos três tipos de símbolos que revelam as posições hierárquicas-sociais de cada um dos personagens principais, a saber: a postura, a linguagem e a forma material com que nos são apresentados. Em relação a postura, fica claro que a de Supriano, em geral, denota medo e solidão, configurando-se, ao longo da trama, como um indivíduo indefeso e delicado, que continuamente encontra-se em situações de risco e dependência. Por outro lado, o modo de se portar do capitão Elpídio transborda segurança, autossuficiência e poder de mando.

Quanto à linguagem, as falas proferidas por Piano são prudentes e cautelosas, evidenciando a sua posição subalterna frente aos demais personagens: "Com perdão da pergunta, mas será que mecê não tem por lá alguma enxada assim meia velha pra ceder para a gente?” (ÉLIS, 1966, p. 88). Oposto a isto, as falas de seu Chaveiro são rudes, depreciativas, com um tom ameaçador que impõe o respeito e a obediência dos demais, fato que reforça, no contexto, sua superioridade: "Cala a boca, sô! Aqui quem fala é só eu. Olha aqui, Piano. Hoje é dia onze. Até dia treze, se ocê num tiver plantado meu arroz, esses dois soldados já tão apalavrados. Vão te trazer ocê debaixo de facão [...] Põe bem sentido nisso e pensa sua vida direito, olha lá.” (ÉLIS, 1966, p. 94).

Por fim, no que concerne a forma material, muitos aspectos podem ser comentados. “Supriano era feio, sujo, maltrapilho" (ÉLIS, 1966, p. 83), e teve sua imagem constantemente atrelada a ausências ao longo da estória, além de não contar com mais do que uma "muda de roupa", possuía uma casa pequena, desprovida de qualquer conforto e proteção, nela: "Insetos e vermes roíam e guinchavam pela palha do teto apodrecida pela chuva. Nos buracos do chão encharcado, escorregadio e podre, outros bichos também roíam, raspavam e zuniam” (ÉLIS, 1966, p. 97). Somado a isso tinha-se a ausência de qualquer meio de transporte próprio, fato que fez com que ele ficasse refém de longas viagens a pé na busca pela enxada: "O comércio ficava meio longinho; de a pé, levava-se bem um dia para ir e voltar. O melhor era sair àquela hora, pousar no Furo. no outro dia chegava cedo à cidade, aí o padre já regressara, pegava a enxada e ainda vinha pousar no rancho" (ÉLIS, 1966, p. 90).

Em contrapartida, Elpídio Chaveiro, além de ser detentor do seu próprio armamento e possuir em sua boca dentes revestidos de ouro, utilizava uma mula grande 
para o seu deslocamento e trajava vestimentas sofisticadas, como botas, esporas e chapéus: "O patrão chegou com rompante, enorme em riba da mulona, as esporas tinindo, as armas sacolejando [...] a boca relumiando ouro por debaixo do chapéu de aba grande” (ÉLIS, I966, p. 87). Ademais, ele era dono de terras e possuidor de um grande poder econômico de compra: "Quem é que não conhecia o costume de Seu Elpídio? Era fazendeiro que exigia que todo mundo pedisse menagem para ele. Ele é quem fornecia enxada, mantimento, roupa e remédio para seus empregados" (ÉLIS, 1966, p. 86).

Investigando o sentido intrínseco ao texto em detrimento aos elementos presentes na concepção de Poder Simbólico, é possível identificar os traços evidentes do coronelismo presentes na estória. Segundo Victor Leal Nunes (1986), tal prática implica no compromisso entre o poder público e o privado, este último representado pelos chamados “coronéis”, que geralmente não são militares de carreira, mas sim grandes proprietários de terras. A aliança entre eles possui o intuito de fortalecer e conceder prestígios mútuos a ambas as partes.

No mundo rural descrito em A enxada (1966) é possível observar a relação de "parceria" entre o público e o privado por meio do mandonismo presente na figura de Elpídio Chaveiro, representando este último e sua relação com o delegado, que desempenha uma figura pública, em nome do Estado. Frente a um cenário jurídico debilitado com ausência da regulamentação de direitos dos trabalhadores rurais, o latifundiário conseguiu, por meio de estratégias próprias, se valer de um poder absoluto. Poder esse que o permitiu, por diversas vezes, na obra bernardiana, se apropriar da força estatal, a exemplo do uso de soldados para garantir que seus negócios e sua imagem fossem respeitados.

Diante disso, é possível perceber que os símbolos incorporados à postura do "coronel” expõem uma séria consequência na narrativa: a marginalização do trabalhador do campo. Esta se dá pelo fato de que o simples camponês é confinado a uma posição inferior na sociedade, sendo ele continuamente explorado e desrespeitado por figuras que se apresentam, econômica e simbolicamente, como seres socialmente superiores. Além disso, essa exclusão também é resultado da falta de aplicação da proteção jurídica, que não incide sobre a figura do trabalhador na obra, em virtude dos obstáculos advindos das mais 
diversas manobras políticas coronelistas em busca de poder e da disrupção quanto às garantias ao acesso ao direito e à justiça.

\section{O DIREITO AGRÁRIO CONSTITUCIONAL E SUAS RELAÇÕES DE TRABALHO NO CAMPO BRASILEIRO}

A década de 1950 e os anos incipientes de 1960 marcaram uma acentuada mobilização no cenário do campo brasileiro. Nesse período, as Ligas Camponesas do país representavam um grupo heterogêneo de trabalhadores rurais, que se organizaram e atingiram a unicidade necessária para transmutar as diligências locais ou individuais do trabalhador do campo em um movimento político-social de maior amplitude contra o inservível e caquético latifúndio.

À época da produção do conto A Enxada, em 1966, dois anos após o golpe militar, "o movimento campesino foi desagregado e a força do latifúndio recrudesceu com o processo de modernização da agricultura levado a cabo pela ditadura, que, sob a lógica do capital, resultou no aumento da concentração da propriedade da terra" (CORRÊA e COSTA, 2009). Assim, a institucionalização da propriedade privada da terra e sua mercantilização tornaram-se a chave para a compreensão das relações de poder no meio rural.

A estrutura fundiária concentrada faz parte da formação territorial do Brasil, uma vez que o processo histórico da colonização foi responsável pelo desequilíbrio nas posses de terras. Ao longo do período colonial era possível obter a posse da terra com relativa facilidade devido à abundância de áreas disponíveis e da utilização de mão de obra escrava para o desenvolvimento e produção. À época, a ordenação que normatizava a distribuição de terras destinadas à produção agrícola foi o sistema português de Sesmaria, adaptado no Brasil sob a égide da escravização. Como regra dessa sistematização, para ter o domínio sobre a terra, era necessário ser uma pessoa livre. Em um país de escravos, poucos eram aqueles que poderiam possuir um imóvel rural.

No ano de 1822, às vésperas da Independência do País, a Lei das Sesmarias foi revogada. Décadas depois, em 1850 , é promulgada a Lei de Terras, que viria a orientar a estrutura fundiária do país. Nessa nova, mas ainda arcaica perspectiva, o direito à terra passou a ser considerado diretamente proporcional a quem tivesse recursos financeiros 
para arcar por ela. Repetindo o histórico de exclusão, grande parte da população brasileira foi suprimida, uma vez que não possuíam capital suficiente. Novamente se operava a lógica mercantilista e desigual de distribuição de terras.

Assim, para Prado Júnior (1981), o latifúndio é um produto do capitalismo. Nesse diapasão, o Estado é responsável pela pacificação dos conflitos entre as classes (MARTINS, 198I). Contudo, não se pode olvidar que o próprio aparelho estatal teve papel crucial no processo de concentração da estrutura fundiária brasileira e, apesar de apresentar instrumentos jurídicos que busquem a democratização do acesso à terra, mostra-se ainda ineficiente frente a tais querelas. Sob esse viés, o Estatuto da Terra, advindo da criação da Lei 4.504, de 30 de novembro de 1964, introduziu mudanças no modo como o direito tratava a relação do homem com a terra, assim como induziu que o Poder Público passasse a condicionar que o não cumprimento da função social da terra infringiria rigores sobre o bem. Aduz Heim e Silveira sobre isso:

Com o Estatuto da Terra, rompendo com os dogmas civilistas de um direito absoluto, à propriedade agrária passou por um processo de funcionalização, onde direitos e deveres eram impostos aos proprietários e não proprietários. O primeiro poderia utilizá-la livremente, desde que ao usufruir das condições econômicas do bem favorecesse o bem-estar pessoal e dos trabalhadores que nela labutam, assim como de suas famílias (...). Aos não proprietários permanecia o dever de respeitar o direito individual, ao tempo que passaram a titularizar o direito de que este bem fosse utilizado nos moldes da função social acima apontados (HEIM; SILVEIRA, 2013).

No entanto, apesar de ser uma importante lei e instrumento de política agrária, a esfera de aplicação do Estatuto ainda revela falhas. Sob esta perspectiva, urge a necessidade da discussão de ferramentas que orientem a aplicação do direito e constituam instrumentos fundamentais para a questão agrária e seus reflexos. Para isso, torna-se imperioso o estudo dos princípios do Direito Agrário Constitucional. Nesse sentido, aborda-se, em específico, os princípios da Dignidade da Pessoa Humana, da Função Social da Propriedade, bem como da Justiça Social no Campo. Estes norteiam a atividade agrária e assumem relevante importância no uso adequado e racional da terra, assim como na manutenção do equilíbrio socioeconômico.

A Constituição Federal de 1988, em seu artigo 5을 do qual se tratam os direitos e garantias fundamentais, introduz que todos somos iguais perante a lei, sem distinção de 
qualquer natureza, sendo garantido aos brasileiros e aos estrangeiros residentes no País a inviolabilidade do direito à vida, à liberdade, à segurança e à propriedade. O direito à terra é, pois, figura inerente ao ser humano e representa um pilar essencial para garantir a sua dignidade, representando a terra um instrumento para o trabalho e moradia ao cidadão. A constitucionalização do Direito Agrário se encontra voltada aos valores essenciais à efetivação da dignidade da pessoa humana e, a uma constituição de uma sociedade mais justa, livre e solidária.

O princípio da dignidade da pessoa humana é o elemento norteador de todos os direitos fundamentais, aqui incluso no direito de todos à terra. É vinculado à ideia de que não é possível a submissão do homem à condição de mero objeto do Estado, mas como um sujeito de direitos e garantias. Assim, delineia-se no sentimento de justiça que denomina a busca de cada povo em perquirição de realizar as suas vocações e necessidades.

A ideia de função social da terra, parte do princípio do bem comum. Trata-se da maneira como a propriedade deve ser utilizada na conjuntura da sociedade em que se circunscreve. Para isso, a produção deve ser consciente e ao mesmo tempo adequada, observando a conservação do meio ambiente e o progresso dos trabalhadores. Conforme Barros (2008, p.63), “o princípio da função social da propriedade rural visa o bem estar coletivo no sentido mais amplo que se possa dar à palavra, relegando ao segundo plano o interesse individual". A Constituição Federal de 1988 consolidou este princípio de modo a intervir na política agrária e limitar o direito absoluto da propriedade da terra no Brasil. Em seu artigo I86, dispõe expressamente as condições necessárias para satisfação desse princípio, assim aludindo:

Art.I86. A função social é cumprida quando a propriedade rural atende, simultaneamente, segundo critérios e graus de exigência estabelecidos em lei, aos seguintes requisitos:

I - aproveitamento racional e adequado;

II - utilização adequada dos recursos naturais disponíveis e preservação do meio ambiente;

III - observância das disposições que regulam as relações de trabalho;

IV - exploração que favoreça o bem-estar dos proprietários e dos trabalhadores (BRASIL, 1988). 
A punição para o descumprimento da função social da terra é a perda da propriedade, mediante ulterior indenização, sendo essa mesma terra destinada para fins de reforma agrária, conforme dispõe o artigo I84 da Carta Magna. No entanto, de acordo com Marés (2010), o artigo I85 da Constituição distorce a conceituação da função social da terra ao restringir as desapropriações, assim demonstrado:

Art. I85. São insuscetíveis de desapropriação para fins de reforma agrária:

I - a pequena e média propriedade rural, assim definida em lei, desde que seu proprietário não possua outra;

II - a propriedade produtiva (BRASIL, I988).

A existência da previsão legal da desapropriação em face do não cumprimento da função social compreende a figura da terra como simples mercadoria, ao passo que em caso de descumprimento da função social, a mera penalidade seria a desapropriação mediante a indenização, possibilitando ao proprietário comprar novas terras e, novamente, não buscar o fim da função social, mostrando-se um ciclo vicioso do monopólio de terras. Nota-se, portanto, que tal instituto não é suficiente para superar a figura do latifundiário, mas apenas pressiona latifundiários a tornarem suas terras produtivas.

Essa maquiagem da lei, frente às dificuldades do acesso da terra, abriu espaço para que os grupos sociais mais vulneráveis trabalhassem e residissem em terras dos grandes latifundiários com remuneração apenas para sobrevivência, sendo cada vez mais alimentada a máquina capitalista e o empobrecimento das classes mais baixas.

O Princípio da Justiça Social no Campo, por sua vez, molda-se ao fato de que as regras de Direito Agrário são voltadas para atender a necessidade de justiça social nas relações no campo, combatendo as desigualdades. Trata-se, portanto, do corpo normativo que tenta expurgar a distribuição desigual de terras, minimizando a figura do latifúndio, com vistas a alcançar a justiça social, bem como o acesso democrático de todos à terra. $\mathrm{O}$ Estatuto da Terra, por sua vez traz consigo a figura da justiça social em seu artigo i6, assim dispondo:

Art. 16. A Reforma Agrária visa a estabelecer um sistema de relações entre o homem, a propriedade rural e o uso da terra, capaz de promover a justiça social, o progresso e o bem-estar do trabalhador rural e o desenvolvimento econômico do país, com a gradual extinção do minifúndio e do latifúndio (BRASIL, I964). 
Do mesmo modo, o art. io3 do mesmo diploma legal preza pelos princípios da Justiça Social, sendo associada com a Liberdade de Iniciativa e a Valorização do Trabalho Humano, devendo ser esses aplicados antes de qualquer outra norma. Assim dispondo:

Art. I03. A aplicação da presente Lei deverá objetivar, antes e acima de tudo, a perfeita ordenação do sistema agrário do país, de acordo com os princípios da justiça social, conciliando a liberdade de iniciativa com a valorização do trabalho humano (BRASIL, 1964).

Através da observação conjunta de tais princípios poderão ser orientadas soluções jurídicas a serem adotadas no caso concreto quando estas se sujeitarem à apreciação do intérprete. Mais que regular relações jurídicas, a compreensão destes permite a coordenação de todo sistema agrário-constitucional.

\section{O DIREITO ATRAVÉS DA LITERATURA DE BERNARDO ÉLIS SOB PERSPECTIVA AGRÁRIO-CONSTITUCIONAL E O DIÁLOGO COM A TEORIA DE PODER SIMBÓLICO}

A intersecção entre Direito e Literatura possibilita o aperfeiçoamento de uma formação jurista e cidadã ao contribuir no universo jurídico, através de obras literárias, em uma visão mais crítica, multifacetada e esclarecedora da realidade humana. Nesse sentido aduz Henriete Karam (2017) que

\footnotetext{
A literatura - que se caracteriza pela dimensão criadora e lúdica, pela flexibilidade e constante renovação da linguagem, pelos efeitos de humanização e empatia que se mostra capaz de produzir, por sua natureza polifônica, sua abertura para a plurissignificação e para múltiplas possibilidades de interpretação - constitui importante recurso tanto para apurar a habilidade de leitura e desenvolver as competências de compreensão e interpretação de textos, essenciais à práxis jurídica, quanto para promover a ampliação do próprio horizonte de compreensão dos juristas e, portanto, a reflexão destes acerca dos fenômenos jurídicos e social (KARAM, 2017).
}

Ainda nesse segmento, a literatura regionalista de Bernardo Élis produzida no ambiente agrário goiano se apresenta como fonte complexa de análise não só do espaço geográfico da região e da realidade social, cultural e simbólica em tempo e espaço determinados, como também universaliza o sujeito ao exprimir seus dramas, conflitos, e profundos anseios humanos.

Considerando a estrutura fundiária do país, o caráter conservador da legislação de terras e o poder da classe dos proprietários rurais na sua relação com o Estado, Élis inserta 
o personagem Supriano e sua labuta na consecução de seu instrumento de trabalho, denunciando as condições degradantes às quais o trabalhador do campo está historicamente submetido.

Nessa perspectiva, cabe analisar a captura dos vínculos entre os personagens e suas relações de desigualdade, hierarquia e dominação. Mais do que liames arbitrários calcados na força, tais relações são permeadas pela compreensão de uma ordem natural e manifesta do poder, tanto para aqueles que dominam, quanto para aqueles que são dominados. Surge, nesse sentido, a teoria discursiva bourdieniana. Preleciona Bourdieu (1989), que o poder simbólico é um poder "invisível” e apenas pode ser exercido com a cumplicidade daqueles que lhe estão sujeitos ou que o exercem, mas que não querem ter consciência disto.

O personagem Supriano, inserido nesse contexto, está custodiado sob um poder simbólico que o atormenta, o escraviza e o aliena, sem o permitir sair do jogo da dominação do coronel Elpídio Chaveiro. Esse impasse presente no espaço diegético representa, em verdade, os intensos conflitos agrários reais que se perpetuam no tempo e no espaço das sociedades rurais. Apesar do Estatuto da Terra já coexistir com a realidade ficcional, o conto denota as consequências da ausência da aplicação das normativas, que transcende o ficcional e impera no cotidiano dos camponeses sob o jugo do trabalho hostil na unidade da fazenda dos latifundiários.

Local fechado pelas cercas farpadas da propriedade privada da terra, onde a submissão do trabalhador aos desmandos dos coronéis vislumbrava a realidade do agregado, um ser humano do campo, sem dinheiro, sempre endividado com o patrão, esfarrapado, sem terra e exposto às injustiças e à exploração. Sujeito protagonista das intempéries da desigualdade, da rudeza e da aguda violência contra os pobres do Brasil agrário da metade do século XX (GONÇALVES, 2018).

O poder dos coronéis e do patriarcalismo - representantes da elite local à época - no interior do país fomenta e reforça a desigualdade, a injustiça, o desmando e o uso impiedoso da força e da brutalidade da classe dominante contra a classe trabalhadora. Ressalta-se, nessa dimensão, que o Estado era comumente representado por esse grupo social prestigiado, detentores do poder ora no âmbito executivo, ora legislativo e, por vezes, na esfera do judiciário.

No conto, o personagem do fazendeiro Elpídio Chaves é filho de senador e autoridade pública local, da qual, consequentemente, sempre lhe caberia obediência pela 
população. Desse modo, o Estado caminha sobre uma ligação entre os homens através de uma relação de dominação, que se operacionaliza mediante uma violência justificada como legítima. Isso corrobora na manutenção da ideia de que haja uma classe dominada submetida à autoridade de uma classe dominante, sendo a política um sistema de dominação. Nesse sentido

\begin{abstract}
A atuação dos coronéis se caracterizava pela defesa dos 'interesses do Estado' mas que na verdade eram a conjunção de interesses privados: além da violência do dia a dia, era muito comum que, até mesmo, as próprias relações de trabalho também fossem truculentas, onde se inserem as relações entre coronéis e camponeses, sobre trabalho e a posse da terra (SILVA et al, 2015, p. 240).
\end{abstract}

Pierre Bourdieu (1989) destaca que a luta pelo poder ocorre igualmente em um espaço simbólico, mediante o monopólio intitulado por ele como "nomeação", sendo este a concepção do senso comum de que é legítima uma imposição oficial para o meio social. Tal imposição é mais facilmente compreendida quando quem os sujeitos que impõem detêm legitimidade estatal, pois uma vez sendo estes mandatários do Estado, seriam também detentores do monopólio de um poder legítimo. Elpídio, personificação do coronelismo, legitima-se como poderoso local enquanto um chefe político, proprietário de grandes extensões de terra.

Em síntese, a estrutura coronelística em Goiás vem a ser estabelecida a partir do acordo político entre elites que detinham o poder local, em decorrência do descaso do governo federal em intervir na região, seja por falta de interesse ou por inviabilidade logística, e do fortalecimento de grupos políticos específicos que detinham o controle da máquina estatal. Esses acordos iriam desde facilitações econômicas, poderes absolutos aos coronéis, voto de cabresto imposto à população sujeita e autonomia aos líderes locais: a manutenção de grandes latifúndios que nunca se desfizeram, a concentração de poder na mão de oligarquias rurais advindas do processo de ocupação desenfreado e o descaso do Estado, além da própria situação de fronteira, que deixava todos os que ali viviam a mercê da força e da oportunidade daquele que conseguissem dominar - elementos persistentes até os dias de hoje em muitas cidades no interior do estado (AGAPITO, 2021, p. Io8).

Contudo, além da legitimação já posta de Elpídio pelas razões acima apresentadas, este ainda explora diretamente o personagem Supriano, que está sob o jugo de sua dominação até o pagamento da dívida pactuada. Piano, um agregado endividado e subordinado ao domínio do influente latifundiário se vê configurado em uma situação de escravidão por dívida. Sendo este um trabalhador honesto, farroupilha, doente e sem os 
meios e objetos para a produção de trabalho, é condenado "a perambular por migalhas de coronéis no Sertão goiano" (GONÇALVES, 2018, p.12).

Aqui percebe-se, contudo, graves violações aos princípios aludidos do Direito Agrário Constitucional. A priori, pondera-se sobre a base do mais elementar Princípio inerente ao homem, a Dignidade da Pessoa Humana. Por se tratar de um valor espiritual e moral inerente à pessoa, no que corresponde à garantia das necessidades vitais de cada sujeito, constitui-se direito fundamental indispensável que deve ser assegurado pelo ordenamento jurídico a fim do pleno desenvolvimento da personalidade de cada indivíduo, do reconhecimento de seu valor intrínseco e da sua titularidade de direitos.

Considerando a trajetória do personagem Supriano, revela-se graves máculas ao mínimo existencial e à vida digna do trabalhador rural. Soma-se a isso a preocupante problemática a separação do trabalhador dos meios e objetos de trabalho, à medida que Piano não detém nem a terra, muito menos a enxada, seu principal instrumento de trabalho.

\footnotetext{
Supriano botou a mão na cabeça: adonde achar uma enxada, meu Divino Padre Eterno! Como desmanchar esse nome feio que the tinha posto o malvado do delegado? Quem será que ia lhe emprestar uma enxada? Ele tinha conhecimento com o coronel, mas este não o serviria. Procurar negociante era pura bestagem. Elpídio estaria já de língua passada com todos eles para não venderem nada a prazo para os camaradas. Quem é que não conhecia o costume de Seu Elpídio? Era fazendeiro que exigia que todo mundo pedisse menagem para ele. Ele é que fornecia enxada, mantimento, roupa e remédio para seus empregados. Ninguém não iria pois vender uma enxada para Supriano (ÉLIS, 1966, p. 51).
}

Em uma sociedade de modelo de produção capitalista, fundado nos mecanismos de mercado, o principal recurso que o indivíduo tem para garantir seus meios de subsistência é o seu trabalho fundado na capacidade física e intelectual que lhe é peculiar. No caso de Supriano, em razão da carência de instrumentos próprios para o trabalho, bem como o seu consequente adoecimento, houve a perda das condições e da capacidade laboral.

A intervenção do Direito para o tratamento dessa problemática deveria ocorrer a partir de prerrogativas que visem garantir o trabalho, assegurando-lhes os meios, e formas de proteção ao trabalhador, salvaguardando a este um padrão de vida digno. Contudo, isto sequer foi garantido à medida que se desdobravam séries de violações ao conjunto mínimo de prestações de sobrevivência a que todos fazem jus (leia-se mínimo existencial), tais 
como a precariedade da moradia, a insegurança do trabalho e a escravidão por dívida - que causou a morte do personagem.

Quanto ao Princípio da Função Social da Propriedade, Dantas (2015) indica que a ideia de uma função social é o reconhecimento de que os interesses do titular do direito precisam se compatibilizar com os de outros cidadãos não proprietários, respeitados e considerados por parte do sistema de direitos construído para a regulação da sociedade como um todo, e em igual medida. Nesse sentido, o Estatuto da Terra, vigente à época da obra, dispõe:

Art. $2^{\circ}$ É assegurada a todos a oportunidade de acesso à propriedade da terra, condicionada pela sua função social, na forma prevista nesta Lei.

$\S \mathrm{I}^{\circ} \mathrm{A}$ propriedade da terra desempenha integralmente a sua função social quando, simultaneamente:

a) favorece o bem-estar dos proprietários e dos trabalhadores que nela labutam, assim como de suas famílias (BRASIL, 1964)

Como bem observado na obra, a terra de Elpídio ao qual Supriano trabalhava não favorecia o mínimo de bem-estar a si, nem a sua família. A sua trágica morte por não conseguir cumprir o pactuado confirma a graveza da concentração de terras e dos abusos cometidos contra a classe trabalhadora e aos camponeses, considerando suas vulnerabilidades diante o sistema.

Quanto ao impulsionamento do princípio da dignidade da pessoa humana dever ser sobreposto às relações de agrárias, aqui visto no dispositivo do o $\S^{\mathrm{I}^{\circ}}$ do $\operatorname{art}$. $\mathrm{I}^{\circ}$ da Lei 4.504/64, serve-se de parâmetro o princípio da Justiça social, sendo consagrado como elemento no artigo I03 do mesmo diploma legal, que preconiza: “A aplicação da presente Lei deverá objetivar, antes e acima de tudo, a perfeita ordenação do sistema agrário do país, de acordo com os princípios da justiça social, conciliando a liberdade de iniciativa com a valorização do trabalho humano" (Brasil, 1964).

Contudo, a alienação da terra a partir da exploração do trabalho, bem como a sociabilidade do camponês e do agregado subordinada à propriedade da terra e ao proprietário, latifundiário e coronel representam na obra bernardiana lesões ao citado princípio, que, apesar de já estar positivado à época não foi devidamente materializado. Perpetuou-se, em verdade, "a representação rigorosa das relações desiguais entre 
latifundiários, posseiros e agregados diante da precária existência nas grandes fazendas goianas" (AGAPITO, 202I).

Configura-se, assim, não só a ausência de leis mais protetivas aos grupos dominados pela elite rural à época, mas a ausência da aplicação fática das normativas já existentes. Em relação ao Direito Agrário Constitucional, não se trata apenas de positiválo, mas de efetivá-lo. Sem sua devida efetivação e limitação dos arbítrios de poderio, perpetuam a servidão dos trabalhadores rurais, uma vez que o poder da classe dos proprietários rurais na sua relação com o Estado parece impedir a disciplina jurídica.

\section{CONSIDERAÇÕES FINAIS}

O conto A Enxada (1966) retrata os contrastes de uma pátria inserida na periferia do capitalismo, de estados e espaços envoltos em uma praxis que reproduz o passado colonial -a exemplo da escravidão por dívidas-, bem como a concentração de terra e a exploração impiedosa sobre os trabalhadores. A narrativa fictícia, em verdade, revela as indignas condições de (sobre)vida de tantos "Suprianos" que existem fora da dimensão diegética, o que permite elucidar uma verdadeira mímesis em que a arte imita a vida ora a vida imita a arte. É nessa perspectiva que Bernardo Élis aduz:

Procurava sublinhar a humanidade do homem sem terra, mostrando a injustiça do latifúndio e da opressão feudal, responsáveis pelo atraso e pelos males sociais de que éramos vítimas. [...] Enfim, minha literatura metia o dedo nas chagas mais dolorosas de uma cultura regionalizada (ÉLIS, 200o, p. 99-100).

A estória compreende a cultura sertaneja juntamente às lutas dos camponeses vilmente explorados em relação às estruturas da oligarquia agrária e do coronelismo. $\mathrm{O}$ trágico fim de Piano representa toda a violência ecoada por séculos no espaço rural brasileiro, bem como a graveza da concentração de terras e dos abusos cometidos contra a classe trabalhadora e aos camponeses.

$\mathrm{Na}$ realidade social narrada no conto, permeada por indignas condições de trabalho, corrupção na seara política, latifúndios arraigados nas paisagens do interior sertanejo em detrimento a total carência daqueles despossuídos de terra (e até mesmo dos meios e objetos de trabalho) explicitam que o Direito não se apresenta ao trabalhador camponês. Este, que deveria estar sob tutela jurídica estatal, considerando suas vulnerabilidades 
diante o sistema, permanece à mercê da opressão da elite rural, sendo por esta explorado ao liminar do desespero, da fome, da exaustão, até a morte.

Percebeu-se, ao fim do trabalho, a expressiva lacuna de aplicação fática do Direito Agrário Constitucional nesses cenários, instrumento que deveria proteger o trabalhador rural, promover a justiça social no campo, garantir a função social da propriedade e o dar as mínimas condições para viver dignamente, mas que resulta em uma positivação falha.

\section{REFERÊNCIAS BIBLIOGRÁFICAS}

AGAPITO, Victor Hugo de Santana. Narrativas da terra: questão agrária e direito no regionalismo literário de Bernardo Élis. Dissertação de mestrado em Direito Agrário Universidade Federal de Goiás - Faculdade de Direito. Goiânia. p. 16r. 202I. Disponível em: $\langle$ https://repositorio.bc.ufg.br/tede/handle/tede/II225〉. Acesso em 28 set. 202I.

BARROS, Ricardo Maravalhas de Carvalho. A função social da propriedade rural como vetora da promoção da dignidade do trabalho humano no campo. Dissertação (Mestrado em Direito) - Faculdade de Direito, Universidade Estadual Paulista, Marília, 2008

BORGES, Júlio César Pereira. Fazenda-roça goiana: matriz espacial do sertanejo e do território goiano. 213f. Tese (Doutorado em Geografia), Programa de Pós-Graduação em Geografia da Universidade Federal de Goiás, 2016.

BRASIL. Constituição (1988). Constituição da República Federativa do Brasil. Brasília, DF: Centro Gráfico, 1988.

BRASIL. Lei no 4.504, de 30 de novembro de 1964. Dispõe sobre o Estatuto da Terra, e dá outras providências. Disponível em: $\langle$ http://www.planalto.gov.br/ccivil_03/leis/14504.htm〉. Acesso em: or out. 2021.

BOURDIEU, Pierre. O Poder Simbólico. 2 ed. Rio de Janeiro: Bertrand Brasil, 1989. 
CORREAA, Ana Laura dos Reis. COSTA. Deane M. Fonseca de Castro. Literatura, trabalho e reificação em A enxada, de Bernardo Élis. In: Ana Laura dos Reis Corrêa; Deane Maria Fonsêca de Castro e Costa; Germana Henriques Pereira de Sousa. (Org.). Literatura e história: questões dialéticas da produção literária em nação periférica. Brasília: CEELL, 2009, v. v.I, p. IoI-II6. Disponível em: 〈http://www.unicamp.br/cemarx/anais_v_coloquio_arquivos/arquivos/comunicacoes/gt 6/sessao2/Ana_Laura.pdf $>$. Acesso em 28 set. 202I.

ÉLIS, Bernardo. Veranico de Janeiro. Rio de Janeiro. Olympio, 1966.

ÉLIS, Bernardo. A vida são as sobras. Organização de José Lino Curado. Goiânia: Kelps, 2000.

ERAS, Lígia Wilhelms. CAMARGO, Wander Amaral. ALVES, Vera Cepêda. Enxada: o trabalho na concepção do conto de Bernardo Élis. Revista Unioeste. V I, n. 2, p. 125-138.

GONÇALVES, Ricardo Junior de Assis Fernandes. "NARRATIVAS DA TERRA”: A QUESTÃO AGRÁRIA EM GOIÁS NA LITERATURA DE BERNARDO ÉLIS. REVELLI-Revista de Educação, Linguagem e Literatura (ISSN 1984-6576), v. Io, n. 2, p. 289-307, 2018

HEIM, Bruni Barbosa; SILVEIRA, Jamile Silva. A institucionalização da política de reforma agrária no estatuto da terra: uma proposta à frente de seu tempo? Revista Jus Navigandi, ISSN 1518-4862, Teresina, ano 18, n. 3589, 29 abr. 2013. Disponível em: 〈https://jus.com.br/artigos/24312〉. Acesso em I out. 202I.

KARAM, Henriete. Questões teóricas e metodológicas do direito na literatura: um percurso analítico-interpretativo a partir do conto Suje-se gordo!, de Machado de Assis. Revista Direito GV, v. 13, p. 827-865, 2017 
LEAL, Victor Nunes. Coronelismo, enxada e voto. $\mathrm{O}$ município e o regime representativo no Brasil. 5 ed. São Paulo: Editora Alfa - Ômega, 1986.

MARÉS, Carlos Frederico. Função social da propriedade. In: SONDA, Claudia; TRAUCZYNSKI, Silvia Cristina (Org.). Reforma agrária e meio ambiente: teoria e prática no Estado do Paraná. Curitiba: Instituto de Terras, Cartografia e Geociências, 2010. v. I, p. I8I-198.

MARTINS, José de Souza. Os camponeses e a política no Brasil: as lutas sociais no campo e seu lugar no processo político. Petrópolis, RJ: Vozes, I98I.

PRADO JÚNIOR, Caio. A questão agrária no Brasil. São Paulo: Brasiliense, I98I.

SILVA, S. D. e; MOURA, T. T. R. L. de; CAMPOS, F. I. A terra dos coronéis no Oeste do Brasil: A cattle frontier, violência e dominação fundiária no Cerrado goiano. Topoi (Rio J.), Rio de Janeiro, v. 16, n. 30, p. 234-259, jan./jun. 2015. 